\title{
Pluralism, Governance, and the New Right in German Memory Politics
}

Jenny Wüstenberg, History, Nottingham Trent University

\begin{abstract}
The memory landscape in Germany has been lauded for its pluralism: for reckoning with the past not only critically but in its many complex facets. Nevertheless, particularly victims of repression in East Germany lament that their plight is not adequately represented and some have recently affiliated themselves with the Alternative for Germany (AfD) party and other groups on the far-right spectrum. This article seeks to explain the seeming contradiction between existing pluralism in German public memory and dissatisfaction with it by tracing how memory activists have shaped memory policy and institutions. Based on extensive interview and archival research, I argue that the infiltration of civil society into the institutions that govern memory in large part explains the strength of critical memory in unified Germany and the country's ability to accommodate a variety of pasts. However, there is also a distinct lack of pluralism when it comes to the rules of "how memory is done," to the exclusion of more emotional and politicized approaches that are sometimes favored by some victims' groups. Using the case of the recent debate about the Hohenschönhausen Memorial, I contend that this explains some of the attraction felt by these groups towards the right.
\end{abstract}

Keywords: Alternative for Germany, commemoration, far right, German Democratic Republic, memorials, memory activism, recognition, victims.

Memory in Germany today is pluralistic in terms of what is represented in public space, but the rules that govern remembrance, by contrast, do not exhibit the same level of openness. I argue in this article that despite the presence of different "pasts" in the memory landscape - from Holocaust to human rights abuses in East Germany to the plight of German forced migrants there is a distinct "code of conduct" that shapes how history is invested with meaning and which commemorative projects receive state support. This dominant governance framework in the memory field means that particularly representatives of victims of Communist repression have felt sidelined and underrepresented - and this has created strategic openings for the new right, especially the Alternative for Germany (AfD), to instrumentalize German memory politics.

Commemorative culture in Germany is clearly multifaceted and pluralistic. The Holocaust and the Nazi past are represented not only ubiquitously, but in a differentiated manner. While monuments erected during the immediate postwar period indiscriminately mourned the 
"Opfer der Gewaltherrschaft" (victims of violent rule), more recent additions commemorate specific groups of victims, name the perpetrators and explain historical context. The German Democratic Republic (GDR) is recalled in terms of repression and its victims, as well as in relation to everyday life and culture. The traumatic episodes of German history are widely represented in public space, but positive aspects of the past-notably memories of democratic revolution—are beginning to find expression as well. And even cultural (one might say trivial) artifacts of remembrance, like the "Schrippe" (bread roll), have taken their place in the line-up. This diversity in the memory landscape is mirrored in public debate, popular culture, and policymaking.

Thus, the contemporary memory landscape appears to be a relatively settled affair in Germany. To a large degree, this can be explained by the fact that the critical reckoning with history has become institutionalized to the point that one can regard it is an integral part of the German state's raison d'état. This process of institutionalization was and continues to be deeply influenced by those civil society activists that demanded a local and comprehensive reckoning with the Nazi past since the 1980s. ${ }^{1}$ These activists, many of whom today staff the state-funded memorial sites, have had a profound and lasting effect not only on the landscape of remembrance but on how state institutions regulate and fund memorials. They have thereby also played a pivotal role in determining how the GDR past was confronted especially after 1990.

In this article, I first provide an overview of the governance framework and activism that has shaped the public memory of the Federal Republic (FRG). I argue that today we see pluralism in the content of public memory overall and a lack of pluralism when it comes to the regulatory framework of remembrance, which is built around seemingly neutral notions of "professionalism." Particularly representatives of political prisoners in the GDR have long voiced 
their dissatisfaction with this framework, as well as with the perceived lack of recognition for their demands. I discuss recent developments at important sites of GDR memory in the context of this regulatory environment in order to explain the attraction felt by some of these activists to the Alterative for Germany party (Alternative für Deutschland, AfD). In particular, I use the case of controversies surrounding the Hohenschönhausen Memorial and its director Hubertus Knabe to understand the political constellation and arguments made by victims' representatives. I conclude by contending that a normative commitment to democratic memory would be served by pluralizing the codes of conduct in memory politics, in addition to its content, in order not to cede this ground to the far-right spectrum.

\section{Institutionalizing Pluralism}

In contradistinction to the notion that the postwar period was one of silence about the past, civil society and interest groups were highly active in seeking to shape public remembrance-but uneven in their rates of success. The most effective memory activists were not those who sought to address Nazism's crimes, but rather those who recalled "German" victims of the war (and erected what Birgit Schwelling calls Kriegsfolgedenkmäler): expellee groups, veterans’ associations, and those representing victims of Stalinist repression. ${ }^{2}$ The Vereinigung Opfer des Stalinismus (VOS) was one of the early advocates for the victims of communism (founded in the early 1950s) ${ }^{3}$ and experienced a distinct rise in membership in the aftermath of the failed popular uprising in 1953 in the GDR. Local chapters of the VOS initiated many monuments, among them one at the Steinplatz in Berlin, which is used for annual ceremonies on 17 June to this day. ${ }^{4}$ Another group, the Volksbund für Frieden und Freiheit (People's League for Peace and 
Freedom) planned and collected donations for a large memorial, also in response to $1953 .{ }^{5}$ Many smaller groups were likewise active. What is important here is not merely that civil society groups were closely involved with shaping the memory of the (East) German past from early on, but that they worked hand-in-hand with state actors, who pursued similar commemorative objectives.

Up until 1989, civic advocates for "German victims" regarded the Christian Democratic Union/Christian Social Union (CDU/CSU) as their natural ally. Conservative politicians routinely frequented expellee gatherings, especially during electoral campaigns. Likewise, the VOS was (and continues to be) proud that Konrad Adenauer once personally attended one of its meetings. From the vantage point of political leaders in the climate of the Cold War and efforts for an everstronger "Westbindung" (allegiance to the West) of the Bonn Republic, the victims of communism were a trustworthy constituency. The central place given to the uprising in 1953 in West German commemorative calendar is symptomatic of this: the day (East) Germans rose up against communist tyranny was marked with a public holiday, stamps, and by naming the main road leading up to the Brandenburg Gate.

The same level of support was not afforded to associations of victims of Nazi crimes and their relatives. Their experiences were not silenced outright, but they were certainly not routinely represented in public space or official discourse. This cannot be explained by a lack of civic engagement among survivors and their advocates. From the earliest days after the war, victims' groups both created their own monuments and demanded that the state mark sites of repression and genocide. Through persistence and sometimes with help from Allied authorities, they were successful in some instances. ${ }^{6}$ The creation of memorials at Bergen Belsen and at the Memorial to German Resistance (in western Berlin's Bendlerblock) are the most prominent of these early 
official memorials. Even these, however, were not adequately funded and only occasionally spotlighted through speeches by important government figures—such as when President Theodor Heuss visited Bergen Belsen in 1952. In the late 1950s, another civic impulse to commemorate Nazi atrocities—Action Reconciliation/Service for Peace - was prevented from effective action in the GDR, but slowly gained momentum in the FRG. ${ }^{7}$ In sum, these efforts during the first three decades after World War II led to a limited level of pluralism: veterans, expellees, and victims of communism were commemorated alongside the Holocaust, but public remembrance can certainly be characterized as largely not self-critical. Moreover, the aesthetics of memory during this period were relatively uniform, with little historical information and standard mnemonic forms such as boulders, obelisks, and Christian symbolism. Memorial texts usually did not specify the identity of victims and definitely not of the culpable. ${ }^{8}$

From the perspective of memory activism and its impact on institutionalized commemoration, the 1960s were not the turning point as which they are often depicted. The student movement surrounding 1968 no doubt gave memory politics new impulses, but it also remained mostly on the level of abstract Marxist critique. During the 1960s, few new memorials were initiated, nor did they make inroads in terms of a more differentiated and critical approach. I argue that the student movement nevertheless had two important memory-political outcomes: first, it weakened official support for the heretofore-dominant memory activism focused on "German victims." Second, the perceived failure of the 1968 revolt spurred the creation of a milieu of "new social movements" during the 1970s and 1980s, in which two key movements for memory were fostered.

These two closely related movements—-the Geschichtsbewegung (history movement), which sought to research and exhibit the history of ordinary people generally, but with special 
attention to the National Socialism, and the Gedenkstättenbewegung (memorial site movement), which focused exclusively on sites of Nazi terror-were instrumental in bringing about a profound shift in Germany's approach to the Nazi past and the Holocaust. In a sense, it is counterintuitive that these movements should have ended up shaping the commemorative institutions of the German federal state. As was typical for the social movement scene in which they were embedded, those engaged in history workshops and Bürgerinitiativen (citizens' initiatives) were often suspicious of the state and preferred autonomous, local action. The activists held vigorous internal debates about whether to accept any governmental funding. However, akin to the process undergone by the Green Party, which emerged in the same milieu in the course of the 1980s, this memory activism became intimately intertwined with existing state institutions and also helped to found new ones. This dynamic of anti-institutional movements shifting into the mainstream can be seen as part of a process of generational change that enveloped late twentieth century societies more generally.

The history and memorial site movements influenced the institutions of memory in Germany in interrelated ways. Each pressured actors at various levels of the state-through social movement tactics and lobbying efforts - to shape the governing structures of memorial institutions. Especially in cases where the movements were instrumental in the creation of new memorials or institutions, they insisted that civil society groups be formally represented in their governing councils. They have also routinely become part of the staff and even the leadership of institutions - both of the ones they helped create and of those previously in existence. Their experience in activism made them highly qualified candidates for the memorial scene's job market overall. In their capacity as staff, they have nevertheless usually retained a civic identity. Many of the individuals I interviewed made no distinction between their activism and their 
professional duties. ${ }^{9}$ While the large memorial institutions in the Federal Republic today are by no means partisan in the party-political sense, their political culture no doubt emanates from the left-wing social movement scene of the 1980s. Through these channels, memory activists brought their ideas and demands for critical history squarely into institutions. The Movements' pedagogical and aesthetic principles have likewise been institutionalized. These include: an emphasis on authenticity and historical accuracy (and relatedly, an embrace of decentralized remembrance); a rejection of overblown emotionality so as to not overwhelm the memorial visitor; the demand to name historical context and perpetrators, rather than focusing mainly on victims; a repudiation of monumentalism and vague rhetoric in memorial design; and advocacy for a differentiated — or pluralistic — examination of victim groups. Thus, the movements have profoundly transformed the character of the memory landscape since the early postwar period. Moreover, the "infiltration" of memory activists into memorial institutions has entailed an emphasis on the importance of reaching out to civil society as a matter of course and to a rejection of overt state interference. Activists and government officials refer to this principle as "remoteness from the state" or Staatsferne. ${ }^{10}$

In the early years after unification, memory activism demanding the critical commemoration of the Nazi past, as well as processes of institutionalizing these demands, continued unabated. In addition, the memory of "German victimhood" was soon (re)discovered as a focus of public debate, with novels by W.G. Sebald and Günter Grass and much media attention signaling that this was no longer a topic monopolized by conservatives. Commemorating the GDR was also the subject of numerous debates and policy activity. Through the Enquete Commissions, the Commissioners for the Records of the State Security Services of the GDR (Bundes- and Landesbeauftragten für Stasiunterlagen, BStU and LStU), and the Federal 
Foundation for Working Through the SED Dictatorship (Stiftung Aufarbeitung), the state created governing structures over new (and dual) sites of memory. In large part because of the imperative to fundamentally overhaul the large Holocaust memorial sites in the GDR (most importantly Sachsenhausen, Ravensbrück, and Buchenwald), a lot of federal monies were invested into the memorial field as a whole and gradually contributed to a pluralized memory landscape. With the creation of the Bundesbeauftragter für Kultur und Medien (Federal Agency for Culture and Media, BKM), the state acquired more routinized intervention capacity in matters of memory. BKM officials sat on governing committees of memorial institutions, convened regular meetings of all institutions in the area of remembrance "before 1945" and separately "after 1945," provided funding, and developed policy proposals. Largely because memory was becoming a routine field of public policy, mechanisms and institutions for addressing the East German past were established rapidly. Many of the newly created institutions also employed former GDR dissidents, some of whom were simultaneously active in various memorial initiatives. All of the federal and state-level commissioners for Stasi records had been active in the GDR opposition movement and some continued their civic engagement. Ulrike Poppe (formerly LStU Brandenburg), for instance, helped to initiate a memorial to a former Stalinist prison in the Berlin neighborhood of Prenzlauer Berg. ${ }^{11}$ In addition, a number of what I have called "pragmatists" (people with no direct personal experience with GDR repression) became active in citizens' initiatives to make memorials — such as the Memorial Lindenstrasse in Potsdam or the Memorial Refugee Camp Marienfelde. From the early 1990s then, the field of GDR memory politics was a mixed one, shaped by both state and civic actors, similar to the one established more gradually and against more state resistance by the western memory activists of the 1980s — but with differing political dynamics. Dissidents and pragmatists were located across 
the party-political spectrum, but they tended to be in the center: neither on the far right, nor on the far left - the latter given the fact that the most prominent far-left party was the PDS (Party of Democratic Socialism, later the Left Party), the successor party to the East German SED. Generally, these types of actors sought compromise and reasoned debate, making them less likely to favor the shrill rhetoric of the right. The long-standing victims' groups such as the vos and newly created ones such as the Federation of Victims' Associations of Communist Dictatorship (Union der Opferverbände kommunistischer Gewaltherrschaft, UOKG) continued to prefer conservative political parties. At the same time, due to the more pluralistic memory political climate of the Federal Republic, the CDU/CSU became less automatic partners for them. As Hugo Diederich (managing director of the vOS) lamented to me in my first interview with him "in the old days, the Mayor of Berlin would come to our commemorative ceremony at Steinplatz. We were much more visible then..."12

Despite the generally favorable conditions for commemoration after 1989, however, civil society activists seeking a more prominent position for memories of repression in the GDR perceived serious obstacles to their demands. There was widespread popular sentiment to "move on" and to dismantle the remnants of the SED regime, including most crucially its border installations. Then there was the emerging narrative of "Ostalgie" (essentially, nostalgia for the Eastern way of life) that for a while seemed to dominate. While Ostalgie is routinely decried by victims of the GDR, Jonathan Bach has demonstrated that it is in fact a complex phenomenon that is not simply about glorifying the past, but allows people to find a way to come to terms with the loss of their accustomed political and material world. ${ }^{13}$ At the same time and in the context of international negotiations over unification and the end of the Cold War, the need to maintain a critical reading of the Nazi past at the center of official memory became raison d'état, while the 
GDR past was not prioritized in policy-making. Moreover, those who had worked hard to achieve a critical approach to the Nazi past - former activists, many of whom had turned into memorial and museum staff — were highly protective of their recently acquired positions of power. Some of them had partisan and cultural disagreements with many of the GDR memorial activists, sometimes rooted in what has been called "blindness of the left eye" — a lack of regard on the part of leftists to take seriously human rights violations by left-wing regimes. What is often analyzed in terms of a competition of pasts is, in large part, competition between groups of activists with such partisan or party-political allegiances and with divergent political cultures. Conflicts over sites of memory were sometimes carried out at a very personal level and produced feelings hurt and mistrust on both sides that continue to impact conflicts over memory to this day.

Thus, former political prisoners of the GDR and others in victims' associations often felt that without their engagement, former sites of repression would not be marked or misrepresented - despite the availability of public funds and state support. Virtually all former locations of incarceration of political prisoners in the GDR, as well as other sites of human rights abuses, such as former Soviet Special Camps, soon had their own associations intent on making sure that those sites be safeguarded and presented in particular ways. These were usually made up predominantly of people who had suffered personally at these places - and often had deep (emotional) scars to show for it. One example of this is what is called the "Human Rights Center" in Cottbus — a former GDR jail that housed many political prisoners — and that continues to be run by a civic association in order to maintain autonomy from state intervention. Held up as an example of what happens when victims cede control is the Memorial at Leistikowstrasse in Potsdam, the site of a former Soviet military police prison. Initially identified and made into a 
memorial by civil society activists, including former prisoners, Amnesty International, and Memorial Germany, the site was then taken over by the Brandenburg Memorial Foundation. Even before the memorial opened to the public, it was rocked by bitter conflicts between some activists and memorial staff, particularly the director Ines Reich. Activists, such as Gisela Rüdiger, saw Reich as a representative of a memorial establishment that sought to sideline their perspectives and they felt excluded from "their" site. Indeed, they were prevented from running tours and distributing material. ${ }^{14}$ Reich and her staff, by contrast, felt that they had a duty to shape the memorial according to the standards of historical research and representation. ${ }^{15}$ Activists continued to protest against the memorial's leadership and the dispute escalated into very emotional interactions that continued to hamper the memorial's work for some time. Due to such conflicts, and despite the availability of state funding and infrastructures, memory activists advocating for sites of GDR repression — particularly victims' groups — argued that their experiences were neither adequately supported nor represented in public space.

\section{Regulating How Pluralistic Memory Is Done}

How can this situation be squared with the fact that, as I have described, the memory of repression in the GDR received considerable state support and that mnemonic pluralism thrived in German institutions after the fall of Berlin Wall? Jan Kubik and Michael Bernhard define pluralists as those who:

... believe that the others are entitled to their own vision. If they disagree with those visions, they are ready to engage in dialogue whose principal aim is the orderly pursuit of 'the truth,' discovery of the areas of overlap among the competing versions ... A serious concern for the pluralists is how to construct a field of memory politics that accommodates competing visions and provides a platform for a dialogue between them. ${ }^{16}$ 
This is very much the situation that was present in German memorials and public funding bodies after 1989: memorial staff were open in principle to commemorating the East German past and allowing new actors onto the scene- as long as Holocaust remembrance did not lose its central position and as long as "the rules" of appropriate commemoration, established through civic struggle since the 1980s, were respected. In line with Kubik and Bernhard's definition, mainstream memory was pluralistic in content and open to dialogue, but not pluralistic when it came to how to organize commemoration and aesthetically depict the past.

The placement of the activists of the history and memorial site movements within institutions of memory had a two-fold impact on the confrontation of the GDR past. On the one hand, these (former) activists and now memorial staff fundamentally believed in the importance of reckoning with historical legacies and of incorporating civil society into this process. From this perspective, GDR memory activists began their advocacy from a much more favorable vantage point than the previous generation of activists who had to struggle to be heard in the early 1980s. From the mid 2000s onwards, the new generation of activists—with their allies in memorial institutions - successfully pushed for state actors to recognize and fund more GDR memory sites. Several state-mandated expert commissions - including the federal-level Commission chaired by historian Martin Sabrow and the Berlin Wall Concept (Berliner Mauerkonzept), as well as a consultation process undertaken by the BKM at the time, Bernd Neumann ${ }^{17}$ — worked to come up with a more comprehensive approach to remembering the GDR in a differentiated manner, alongside and in interaction with the Nazi past. This was achieved both through lobbying and contentious activism — including such actions as the installation of over a thousand black crosses at Checkpoint Charlie. ${ }^{18}$ This "rogue memorial" was initiated by the controversial director of the Haus am Checkpoint Charlie Museum and (unsuccessfully) 
defended from demolition in 2005 by allied activists. Interestingly, despite the broad rejection of the installation as historically inaccurate and problematic, it was precisely such contentious action that compelled state actors to spring into action. Officials realized that if they did not put forward an official plan, others would do so in an unregulated manner. Through the interplay of state planning and civic challenge, we have thus seen the development of a more pluralistic memory landscape, in which the GDR has been granted a prominent position. This state-led investment — and the growing age of GDR victims — has led to an increasing professionalization of memory work on the GDR (in parallel to work on the Nazi past) and a decreasing involvement of "witnesses" (Zeitzeugen). This development is viewed critically by advocates for GDR victims, as I discuss below.

Those activists from the 1980s, who have now become memorial officials, have helped to devise — and vigorously defend — a regulatory framework for memorial institutions that also applies to the commemorative sites about the GDR and therefore strongly shapes the "way in which memory is done" across the board. Andrew Beattie distinguishes between "official" memory, which is produced directly by state representatives, and "state-mandated" memory, which is promoted by other actors, while being subsidized or endorsed by "the state." Memory policy today is a mixed field, in which state agents operate both proactively and more indirectly. Beattie contends that new state funding instruments after 1990 did not result in state control. ${ }^{19} \mathrm{I}$ have likewise argued that the rules governing memory today were not simply imposed by the state on society; instead, they were jointly created by memory activists and institutional actors (although these two categories are not always easy to distinguish in practice) ${ }^{20}$ This framework enshrines the memorial principles introduced by the earlier activists, as well as, in the course of the conflicts over sites of dual past, the "Faulenbach Formula," 21 which acts as an important 
safeguard of memory pluralism. Interestingly, the idea of Staatsferne - that the state should not intervene directly — is widely lauded, despite the fact that state actors routinely intervene through funding decisions, the organizations of meetings, the issuance of guidelines, and more. In other words, this suggests a particular, agreed-upon notion of nonintervention.

State actors do not surreptitiously govern the pluralistic memorial landscape; but they do set certain parameters by acting as the initiators of activist networking and by influencing the standards that must be met to have access to key players and resources. Drawing on Michael Foucault's concept of governmentality, Thomas Lindenberger argues that "in order to gain recognition as legitimate policy, those responsible have to demonstrate that they can handle the intricate logics and rationalities that define the common ground of the governing and the governed in this field" of public memory. ${ }^{22}$ One of the central criteria for admission into networking forums and funding relationships is "professionalism" on the part of the institutions and actors involved. The use of "professionalism" as a distinction invokes a whole set of unwritten but widely understood principles of conduct, including most importantly an objective handling of historical facts, a reasoned (and not overly emotional) approach to memorialization, and restraint in politicizing remembrance. These are principles that were developed in the context of the two movements I discussed above and in the process of turning former sites of Nazi terror into venues for democratic political education. The former activists have become the standard-bearers for "professional conduct" in German memorialization. These standards, however, advantage historians and other experts over victim advocates who approach commemoration through experience. According to Lindenberger, scholarly experts take on a crucial role in legitimating professionalism and privileging it over the needs of "non-neutral witnesses" to the past. ${ }^{23}$ Many of the newer activists have found ways to make their demands 
heard while adhering to this framework of professionalism. They have themselves become successful members of the "memory establishment," doing much to pluralize the German memory landscape in terms of various pasts that are represented, but also thereby working to reproduce the framework of rules on which it is built. Nevertheless, there are also those who have not been able or willing to adopt this code of conduct and who have challenged the existing rules by using rhetoric and mnemonic design ideas that do not easily fit in. They variously emphasize their need for spaces of mourning (rather than only of historical learning); for recognition and for honoring sacrifice; or for transmitting their experiences to younger people, sometimes through shocking images or artistic expression.

This suggests that those who do not speak the language of professionalism—but who have legitimate concerns to voice in the process of working through remembrance-may be denied access to crucial memory policy forums or official funding. In the eyes of Gisela Rüdiger, a long-time advocate for memorials at Lindenstrassse and Leistikowstrasse in Potsdam, activists are routinely accused of a lack of professionalism, or of being fanatics, in order to exclude them from decision-making about how the communist past is represented. ${ }^{24}$ She told me that:

while, in a scientific study, history can and must be examined in a very differentiated way, at a memorial, an evaluation must take place. With every exhibition, an evaluation of artifacts is made - through the selection of documents and the emphasis made through the order of display - and generalizations and judgments are made. We demand, for example, that it becomes absolutely clear to a visitor of the exhibit that resistance to the dictatorship of communism/Stalinism was a good thing and that the commemoration of the victims has an adequate place in a memorial, in addition to a framing the general historical context. ${ }^{25}$

Rüdiger sees an active campaign to eliminate "radical anti-communism" as a positive notion at these sites and to thereby "save" the idea of communism, given that it continues to have many adherents. ${ }^{26}$ While I do not endorse this assessment of motivations for those who demand professionalism in German memorials, I contend is that it is precisely because activists such as 
Rüdiger contest mainstream modes of memory, that they have a crucial contribution to make to the development of democratic memorial culture. One of the implications of this argument is that when these demands are not heard or even rejected in the mainstream, they open up opportunities for the far right. I will illustrate this point by examining recent developments in Hohenschönhausen and the dispute surrounding its former director.

\section{Hohenschönhausen and the Far Right}

The Memorial Hohenschönhausen (HSH), the well-known remand prison of the East German security police (Stasi), has taken on an important role for memory politics in contemporary Germany: both as the pivotal monument to GDR repression in the eyes of its victims ${ }^{27}$ and as the focal point for concern about victims' groups affinity for the far right. Carola Rudnick's account of the founding HSH as a memorial site makes clear that victims' associations regarded it as the central institution for remembering the "second German dictatorship" in direct correspondence to the Topography of Terror as the central site on the reign of Nazi terror. ${ }^{28}$ But from the beginning, the debates around HSH also saw conflict between the approach favored by conservatives and victims (using the language of antitotalitarianism, drawing analogies to National Socialism, and seeking to delegitimize the power of the SED that was thought to still be partially in operation) and the historically grounded, neutral, multiperspectival—in other words, pluralistic —approach that was ultimately implemented in much of the GDR memorial landscape. This was also encapsulated in the choice of name for the site: Memorial Hohenschönhausen, rather than "Central Memorial to the Victims of Communism." ${ }^{29}$ According to Rudnick, in the context of this contention, the selection of Hubertus Knabe as the director of HSH was seen as a major victory for conservatives and former political prisoners. ${ }^{30}$ Knabe published widely on the crimes 
committed under communism and the (continued) power of the $\mathrm{Stasi}^{31}$ and gave HSH its unusual character, mandating guided tours given mainly by witnesses, initially without provision of a permanent historical exhibit (though one has since been added). Given the nonexistence of any other "central" monument to the victims of communist regimes (as demanded by the associations), Hohenschönhausen has continued to hold a crucial position both for touristic demand and in the eyes of victims. This makes the recent series of scandals and debates about the site especially meaningful for the character and political orientation of the GDR memory scene writ-large.

The dismissal of Hubertus Knabe from the directorship of HSH in response to complaints of female staff at the memorial about sexual harassment by Knabe's deputy may at first glance seem more related to the \#metoo than the far-right movement. But, it has in fact played into a fundamental (and not yet concluded) debate about whether GDR memory organizations have been "infiltrated" by the far right. The GDR memorial scene has dealt with accusations of right-wing affinity before. Rainer Wagner, evangelical minister and the head of the Federation of Victims' Associations of Communist Dictatorship (UOKG), resigned in 2015 after an Islamophobic sermon from 2006 had come to light. Wolfgang Christian Fuchs, a Commissioner of the UOKG, and since August 2014 President of the International Association of Former Political Prisoners and Victims of Communism (InterAsso) sits on the steering committee of the "Christians in the Alternative for Germany" (Christen in der AfD). Concerns about right-wing involvement were also raised in connection with the conflict over the Memorial Leistikowstrasse and the physical attack by a former political prisoner on the memorial's director Ines Reich. ${ }^{32}$ In November 2017, the Support Association (Förderverein) Hohenschönhausen, which advocates and fundraises for the memorial, made headlines for admitting Georg Pazderski, the leader of the Berlin AfD, as a 
member. ${ }^{33}$ The (former) head and founder of the Förderverein is Jörg Kürschner, a West-German who had smuggled illegal literature into the GDR and had been incarcerated, including in HSH, for two years. ${ }^{34}$ Kürschner had defended and advocated for the admittance of Pazderski and had then himself become an object of contention when he began writing regularly for the right-wing newspaper, Junge Freiheit. ${ }^{35}$ After multiple meetings of the Förderverein leadership, of the membership, and with Knabe, the memorial leadership decided to discontinue its association with the Förderverein in June 2018, despite Kürschner having since stepped down as its chair. According to the Berlin daily Tagesspiegel, Knabe justified this move by arguing that it was not always clear to outsiders that the Förderverein is separate from the memorial and that the internal conflicts were harmful to HSH as an institution. Moreover, the newspaper reported that SPD politician Stefan Hilsberg, another founding member of the Förderverein, had criticized the repeated endorsement of AfD positions by Kürschner. ${ }^{36}$ The issue of AfD affinity likely weighed heavier because Knabe had only just been confronted with a similar problem. In May 2018, HSH discontinued the employment of former political prisoner Siegmar Faust as a memorial guide after he had given an interview in which he criticized the length of the jail sentence of Holocaust denier Horst Mahler (he later stated that he strongly disagrees with Mahler's opinions). Faust was also accused of adopting positions that were aligned with the AfD. ${ }^{37}$ In response, the vOS newsletter Freiheitsglocke commented that:

We've long known what happens to public personalities - and Siegmar Faust is one of these - who dare to hold an opinion that is not popular. Of course, it is not as it was in the GDR, where one got six years in the can when you were so bold as to speak or write the truth. We are protected by the law. It protects us from incarceration. But unfortunately, it does not protect us from discrimination whatever it may be: media reprimands, insults, threats, loss of jobs ... ${ }^{38}$

The notion that those who speak an uncomfortable truth are subject to recriminations and silencing is a common one among members of victims' associations and often linked to a sense 
that one is resisting an establishment or elites in a similar way as dissidents did during the GDR.

At the same time, a clear differentiation is made ("thankfully this is not the GDR"), but the spirit of resistance is described as one that was developed in the struggle against the communist regime.

Hohenschönhausen experienced its deepest crisis in the summer and fall of 2018. In September it culminated in the suspension and then firing of Knabe because he had failed to react to sexual harassment committed by his deputy Helmuth Frauendorfer (reportedly the accusations were known to Knabe since early 2016) and allowed a culture of sexism to persist. This decision was broadly supported in the Board of Trustees, including by the head of the UOKG, Dieter Dombrowski. ${ }^{39}$ In December 2018, Knabe reached a settlement, and his successor (historian Helge Heitmeyer) was named in summer $2019,{ }^{40}$ but there continues to be speculation in the press and especially among victims' representatives that the "real" reasons for Knabe's dismissal are to be found elsewhere. In February 2019, the liberal party FDP, supported by the AfD, in the Berlin Senate demanded a commission of inquiry in order to determine what happened and whether Knabe's firing was justified or in fact politically motivated, especially given that the current cultural senator who is responsible for the memorial is Klaus Lederer of the Left Party. The commission did not get instated as the CDU did not support the measure, and looks unlikely that it will be in the future. ${ }^{41}$ It is in this context that AfD parliamentarian Trefzer gave the speech in which he said:

Today we are speaking again about the future of the Memorial Hohenschönhausen. This concerns the installation of an inquiry committee and the clarification of circumstances that led to the dismissal of Hubertus Knabe. But this is about more ... The reckoning with the injustice committed in the GDR is facing an inflection point that will shape the confrontation with the history of the second German dictatorship not only in HSH and Berlin but much more broadly than that. This is now about nothing less than the question of how we can safeguard the foundation for a critical reckoning with GDR injustice and prevent a roll-back towards an a-historical trivialization of the GDR. ${ }^{42}$ 
Trefzer here used the occasion of the parliamentary debate about Knabe to conjure up a moment of crisis for the commemoration of injustice in the GDR and to suggest that victims' stories (and historical truth itself) are under challenge. In this way, the AfD positioned itself as a defender of and advocate of victims' interests and elevated the "causa Knabe" in a manner that politicized the sexual harassment issue. A similar sentiment was transmitted in a report about the meeting between a group of victims' representatives and the Thuringian AfD faction in the vos newsletter, entitled "Should the truth not remain the truth, or will it vanish?" 43 The associations of GDR victims generally state their rejection of extremism on both sides of the political spectrum. However, they similarly link the Knabe scandal to fundamental questions of commemoration. There is broad agreement among victims' advocates that Knabe was a crucial defender of their positions and that he was most likely removed because he was often "unbequem" (uncomfortable) for the political establishment. They believe that his dismissal is most likely politically motivated. Though some of them criticize his difficult personality and do not doubt that he may well have been lacking in leadership qualities, they argue that sexual harassment by a subordinate is insufficient grounds for Knabe's dismissal, especially not without prior warning. ${ }^{44}$ As vos Managing Director Hugo Diederich asked in this context: "Where are we heading, what are we still worth? To whom are we still—really—worth something? The decision about the successor to Knabe will provide an answer. Though it may be a bitter one." 45 The strength of the populist right in Germany is a relatively new phenomenon, so its relationship to memory politics will continue to evolve. It is too early for a comprehensive assessment. But a few important trends can nevertheless be identified. First, the AfD and the populist right more generally, seems to be able to tap into a generalized sense that East Germans' experiences has not found adequate recognition in the unified state. As Norbert Frei, Franka 
Maubach, Christina Morina, and Maik Tändler have recently contended, many East Germans feel a deep-seated disappointment with the unification process that the AfD and others have skillfully activated. Not the "Aufbruch" (transformation) but the demotion after the transformation was identity-forming and the notion that east Germans are being defamed and sidelined "just like back in the GDR" has great mobilizing potential. While many East Germans temporarily developed a new kind of "movement identity" through the revolution of 1989, they do not see this identity meaningfully represented in a unified historical consciousness. ${ }^{46}$ The long-running dispute about the so-called unity memorial in Berlin is only the most recent indicator of this. The lack of political will and funding devoted to the "Einheitswippe," long-discussed and delayed memorial to the 1989 revolution and unification, has been mentioned repeatedly to me as well in a tone of resignation. Relatedly, Julian Göpffarth argues that support for the AfD draws on what he calls "multidirectional nostalgia"_-both for the pre 1933 "innocent" past and a negative nostalgia for the communities and culture of resistance to the GDR regime. ${ }^{48}$ This kind of feeling of common cause rooted in a long-standing experience of resistance also binds together many of those active in GDR memorials, who feel that their accomplishment was not only to resist the GDR at great personal cost, but also to make this past meaningful in the Federal Republic — against the perceived reluctance of the "mainstream." Numerous comments made particularly in the Freiheitsglocke and online suggest that former political prisoners often feel that they are once again in a position of resistance - this time not to a dictatorial regime, but to a powerful establishment that seeks to silence or marginalize them. This is a sentiment that the AfD or PEGIDA (Patriotic Europeans against the Islamization of the Occident) may well be able to tap into with slogans like "wir sind das Volk!" 
Second, victims of repression in the GDR have a complex understanding of and relationship with political parties. Most of those I have interviewed would probably position themselves at the center-right of the political field, but they often voice their concern that the political establishment pays more attention to extremist tendencies on the right and largely ignores left-wing extremism, in which category they include the continued strength of former members of the SED and Stasi. Concomitantly, victims of the GDR are often outraged by what they see as the normalization and integration into mainstream politics of the Left Party as the direct successor to the SED that therefore has a clear conflict of interest when it comes to remembering the crimes of the regime. From this vantage point, the fact that a representative of the Left, Lederer (notwithstanding his relative youth), is responsible for Berlin memorial institutions such as HSH in his capacity as cultural senator, appears as a scandal. There is a sense that the mainstream parties (no longer) seem to care about the memory of GDR repression, and there is particular disappointment with the CDU that was long regarded as a natural ally. The CDU under Merkel has shifted to the left according to Jörg Kürschner. ${ }^{49}$ So it may appear refreshing when AfD takes the kind of clear stance in support of victims as is evident in the speech of Trefzer who declared that "The AfD is firmly on the side of the victims!" also be manifest in Padzerski's joining of the Förderverein.

Victims' representatives, however, are by no means uncritical of the AfD. Rüdiger clearly rejected the party (even as she voiced some compatible memory-political positions) and told me about a recent incident where AfD members were expelled from the Sachsenhausen memorial for shocking behavior, including Holocaust denial. ${ }^{51}$ For Hugo Diederich, the AfD appears as a largely unknown entity ("unbeschriebenes Blatt.") He recounted that before the last election, the vos had requested of all parties to be informed about their positions on issues of importance 
(including pensions for victims). Of all the parties, he said, the Greens had the best positions; the SPD and the AfD never even responded. Diederich also told me that several members of the vOS were members of the AfD and that he thought that most east Germans regard it as a "regular party" - one that you might want to vote for if policy positions align. ${ }^{52}$ Kürschner-who in his capacity as writer for the Junge Freiheit is clearly situated on the far right-also told me that some members of the Förderverein were in the AfD and that he therefore did not understand the concern over admitting Padzerski, who is regarded as relatively moderate. ${ }^{53}$ Kürschner, in my recent interview with him, clearly rejected Björn Höcke's call for a 180-degree turn in the German memory politics ${ }^{54}$ and said that he would have absolutely rejected someone like Höcke from the Förderverein. Thus, some victim representatives would likely advise viewing the AfD or the populist right in a differentiated manner, rather than summarily as an outright threat to democracy. Though this is not a position with which I agree, I do not believe that those who hold it should be automatically regarded as displaying far right affinities themselves.

Third, a common response to the crisis in HSH is the perception that those who insist on the importance of remembering the GDR as a repressive dictatorship are often wholly vilified as right wing, regardless of their statements or opinions. This was the assessment of the purpose of an event that was organized by the anti-discrimination association Amadeu-Antonio-Stiftung on 14 February 2019 in Berlin. The invitation to the event "The right-wing fringe of GDR memory" asked for example whether the "working through of the SED dictatorship was not for some a Trojan horse for a nationalist and antidemocratic agenda." 55 This was met with outrage by victims' representatives, who suspected a conspiracy to keep them out of the event and who organized protests on the day. On his website, Knabe commented that there was a long tradition in the SED of slandering opponents as fascists ${ }^{56}$ _again suggesting strong continuities between 
the two "systems." Vera Lengsfeld, the former GDR dissident and clearly aligned with the right, was at the forefront of online protests against the event and promoted a petition on change.org, calling for an end to public funding for the Amadeu-Antonio-Stiftung. In most of these texts, the authors do not fail to mention the fact that the foundation's director, Annette Kahane had worked for the Stasi-something she has spoken about openly.

In sum, the current political debate and governance situation with respect to the memory of repression in the GDR provides several openings for far-right memory-political overtures. Seeking to understand the demands and motivations of advocates for GDR memory rather than dismissing them outright can be an important antidote.

\section{Conclusion}

In contrast to the memory activism by Holocaust survivors during the first decades after 1945, civic mobilization for reckoning with the Nazi past since the 1980s has had a profound influence on both the landscape and the governance of memory in (West) Germany. A key outcome of this influence has been the institutionalization of mnemonic pluralism in terms of the content of remembrance. The state no longer has to be persuaded that support for the remembrance of a diversity of historical experiences is part of its mandate. To a large degree, this is because not only the principles espoused by memory activists, but also the activists themselves have found permanent homes within official memorial institutions. This success story for critical remembrance is bound up with the establishment of a powerful regulatory framework, along with dominant codes of conduct for memorial-makers and audiences alike. These do much to shape how the memory of repression in the GDR is represented in public. This has some potentially 
negative side effects. As Habbo Knoch, formerly the director of the Memorial Foundation of Lower Saxony, contends, the preservation of codes of conduct about "acceptable" remembrance may not only produce discomfort among visitors in response to the implicit expectations present in memorials. Worse, they hold the danger of evoking active resistance to memorials and the norms they encapsulate as places that now represent a raison d'état. In other words, memorial sites' loss of civic identity and openness to challenge from the outside may not only entail a disconnect with society writ-large, but a rejection of the normative messages about critical remembering that the movements of the 1980s fought so hard to popularize.

The rigidity of the memorial code of conduct in the pluralistic landscape of memory has made some newer memory activists, particularly victims of repression in East Germany, feel that their voices are not adequately heard or represented or that they have been dismissed as unprofessional or radical. Their challenges to the mainstream standards of professional commemoration has sometimes led to their side-lining in the Aufarbeitungsszene. Other times, these activists have decided to exercise the "exit" option, ${ }^{57}$ seeking to create memorial spaces that are relatively autonomous from state intervention, such as the "Human Rights" Memorial in Cottbus.

German memory culture today then, can be described as pluralistic in content but relatively homogenous in its regulatory framework. This situation opens up a potential space that can be occupied by right-wing populists. As I have shown, the AfD rhetoric of support for victims of GDR repression takes advantage of the perceived lack of pluralism in "how memory is done" in official institutions. The victims' dissatisfaction and feeling of being marginalized and even of being accused of "right-wing contamination" makes this rhetoric potentially even more attractive. Moreover, the shifting party-political landscape in unified Germany has removed the 
CDU/CSU as automatic partners for victims of communism. The potential attractiveness of the AfD to victims' groups notwithstanding, it must be stressed that most memory activists in this arena are sophisticated observers of politics and not supportive of the far right.

Nevertheless, it is important to build an understanding about why far-right discourses about the past might be attractive — one that goes beyond the postulation of unreconstructed nationalism or lack of "learning from history." We cannot address problematic norms promoted by these discourses by making the historical experiences and responses that are expressed by GDR victims illegitimate and taboo. Those experiences need to not only given a space but also one in which the state (or those who represent it) does not dictate how the past should be remembered. While the memory culture that has become institutionalized and legitimized by the memory activists of the 1980s is a crucial guarantor of pluralism and democratic remembrance, the framework for governing memory should not become so ingrained that it is no longer open to challenge. Challenges to the mainstream are important indicators that cultures of memory should strive to remain receptive to actors that unsettle the rules on which they are built.

Jenny Wüstenberg is Associate Professor of Twentieth Century History and Director of the Centre for Public History, Heritage and Memory at Nottingham Trent University. She received her $\mathrm{PhD}$ at the University of Maryland, College Park and has since then held academic positions at American University, the Free University Berlin, the Commission at the Federal Ministry of Justice for the Investigation of its Nazi Past, and York University in Toronto. Her research interests revolve around memory activism and politics in Germany, Europe, settler colonial societies, and in transnational networks. Her most recent project examines the comparative remembrance of family separation policies. Wüstenberg is also the co-founder and Co-President of the Memory Studies Association.

\section{Notes}

${ }^{1}$ Jenny Wüstenberg, Civil Society and Memory in Postwar Germany (Cambridge, 2017). 
${ }^{2}$ Birgit Schwelling, "Die 'Friedland-Gedächtnisstätte,"' Zeithistorische Forschungen--Studies in Contemporary History 5, no. 2 (2008): 189-210.

${ }^{3}$ David Clarke, "Constructing Victimhood in Divided Germany: The Case of the Association of the Victims of Stalinism (1950-1989)," Memory Studies 11, no. 4 (2018).

${ }^{4}$ Alexander Richter, "Aus der Geschichte der vos" in Vergeßt uns nicht - Wenn auch die Tage wandern und die Jahre. Eine Festschrift zum 50-Jährigen Bestehen der Vereinigung der Opfer des Stalinismus, ed. Vereinigung der Opfer des Stalinismus e.V. (Berlin, 2000).

${ }^{5}$ Edgar Wolfrum, Geschichtspolitik in der Bundesrepublik Deutschland: Der Weg zur bundesrepublikanischen Erinnerung 1948-1990 (Darmstadt, 1999).

${ }^{6}$ Margarete Myers Feinstein, Holocaust Survivors in Postwar Germany, 1945-1957 (New York, 2010).

${ }^{7}$ See www.asf-ev.de/de/ueber-uns/geschichte/shnezeichen-ost-und-west/asf-geschichtenach-teilung.html; and interviews with Christian Staffa, Action Reconciliation, 17 May 2006; Thomas Lutz, Gedenkstättenreferat, 18 May 2006

${ }^{8}$ Ulrike Haß, "Mahnmaltexte 1945 bis 1988 - Annäherung an eine schwierige Textsorte." Dachauer Hefte 6 (1994): 135-61.

${ }^{9}$ Interviews with Thomas Lutz; Bernt Roder, Prenzlauer Berg Museum, 2 June 2006; Norbert Kampe, Museum House of the Wannsee Conference, 4 May 2006-among others.

${ }^{10}$ Email correspondence Christian Freiesleben, Federal Cultural Ministry, 28 September 2007; Interview Günter Schlusche, Berlin Wall Memorial, 15 January 2014.

${ }^{11}$ Interview with Ulrike Poppe, 10 January 2013.

${ }^{12}$ Interview with Hugo Diederich, vos, 13 December 2012. 
${ }^{13}$ Jonathan Bach, What Remains. Everyday Encounters with the Socialist Past in Germany (New York, 2017).

${ }^{14}$ Interview Gisela Rüdiger, 5 March 2013.

${ }^{15}$ Wolfgang Benz, ed., Ein Kampf um Deutungshoheit. Politik, Opferinteressen und historische Forschung. Die Auseinandersetzung um die Gedenk- und Begegnungsstätte Leistikowstrasse Potsdam (Berlin, 2013).; Interview Anna Kaminsky, Stiftung Aufarbeitung, 10 February 2014.

${ }^{16}$ Jan Kubik and Michael Bernhard, "A Theory of the Politics of Memory" in Twenty Years after Communism. The Politics of Memory and Commemoration, ed. Michael Bernhard and Jan Kubik (Oxford, 2014)., 13, emphasis in original.

${ }^{17}$ Rainer Klemke, "Das Gesamtkonzept Berliner Mauer" in Die Mauer. Errichtung, Überwindung, Erinnerung, ed. Klaus-Dietmar Henke (Munich, 2011)., Martin Sabrow, Rainer Eckert, Monika Flacke, Klaus-Dietmar Henke, Roland Jahn, Freya Klier, Tina Krone, et al., eds. Wohin treibt die DDR-Erinnerung? Dokumentation einer Debatte (Bonn, 2007).

18 Jenny Wüstenberg, "Transforming Berlin's Memory: Non-State Actors and GDR Memorial Politics Today" in Remembering the German Democratic Republic: Divided Memory in a United Germany, edi. David Clarke and Ute Wölfel (Basingstoke, 2011).

${ }^{19}$ Andrew H. Beattie, "The Politics of Remembering the GDR: Official and State-Mandated Memory since 1990" in Clark and Wölfel (see note 18).

${ }^{20}$ Wüstenberg (see note 1$)$.

${ }^{21}$ Historian Bernd Faulenbach put forward an ethical principle with which to address the conflict between the Nazi and GDR past: "Nazi crimes may not be relativized through the reckoning with Stalinist crimes. Stalinist crimes may not be minimized through the reference to Nazi crimes." It has since been cited repeatedly, including in the final report of the Second Enquete Commission: 
Deutscher Bundestag, 13. Wahlperiode, "Schlußbericht der Enquete Kommission Überwindung der Folgen der SED-Diktatur im Prozeß der deutschen Einheit' Drucksache 13/11000, 10 August 1998, 240.

22 Thomas Lindenberger, "Governing Conflicted Memories: Some Remarks About the Regulation of History Politics in Unified Germany" in Clashes in European Memory. The Case of Communist Repression and the Holocaust, ed. Muriel Blaive, Christian Gerbel and Thomas Lindenberger (Innsbruck, 2011)., 81

23 Ibid.

${ }^{24}$ Phone interview with Gisela Rüdiger, 29 March 2019 and email communication, 24 June 2019.

${ }^{25}$ Gisela Rüdiger, email communication, 24 June 2019

26 Ibid.

${ }^{27}$ Sara Jones, The Media of Testimony. Remembering the East German Stasi in the Berlin Republic. Palgrave Macmillan Memory Studies (Basingstoke, 2014).

${ }^{28}$ Carola S. Rudnick, Die andere Hälfte der Erinnerung. Die DDR in der deutschen Geschichtspolitik nach 1989 (Bielefeld, 2011).

${ }^{29}$ Ibid. 328-9

${ }^{30}$ Ibid. 330

${ }^{31}$ See especially Hubertus Knabe, Die Täter sind unter uns: Über das Schönreden der SEDDiktatur (Berlin, 2008).; Hubertus Knabe, Honeckers Erben. Die Wahrheit über die Linke (Berlin, 2009).

${ }^{32}$ Martin Jander, "Kultur der Aufrechnung: Erneuerte deutsche Opfermythologie und Radikaler Antikommunismus. Die Union der Opferverbände kommunistischer Gewaltherrschaft (UOKG)" 
in Ein Kampf um Deutungshoheit. Politik, Opferinteressen und historische Forschung. Die Auseinandersetzung um die Gedenk- und Begegnungsstätte Leistikowstrasse Potsdam, ed. Wolfgang Benz (Berlin, 2013). Jander has, it must be pointed out, been strongly criticized for his aggressive argumentation here and elsewhere. See "Der Rechte Rand der DDR-Aufarbeitung. Bericht von Benjamin Baumgart;" available at http://www.uokg.de/2019/02/der_rechte_rand/, accessed 16 February 2020. 33 "Konflikt um AfD-Mitgliedschaft Verein streitet über Pazderskis Aufnahme," Berliner Zeitung, 5 November 2017.

${ }^{34}$ Interview with Jörg Kürschner, 5 May 2006.

${ }^{35}$ Phone interview with Jörg Kürschner, 29 March 2019. Andreas Speit refers to Junge Freiheit as the "publishing mother lode" of the German right. Though the weekly has made efforts not to be closely associated with the "scene," its editorial positions and headlines are very much in line with AfD rhetoric: Andreas Speit, Bürgerliche Scharfmacher. Deutschlands Neue Rechte Mitte (Bonn, 2017). 156, 160.

36 “Stasiopfer-Gedenkstätte kappt Zusammenarbeit mit Förderverein," Der Tagesspiegel, 19 June 2018.

37 "Holocaust-Äußerung: Stasi-Gedenkstätte Hohenschönhausen trennt sich von Siegmar Faust," Berliner Zeitung, 31 May 2018.

${ }^{38}$ Freiheitsglocke, September/October 2018 68, no.791 (author's translation).

39 “Wie es zur Entlassung von Hubertus Knabe kam,” Der Tagesspiegel, 10 October 2018.

40 “Die Stasi-Gedenkstätte bekommt einen neuen Direktor,” Die Zeit, 17 June 2019.

${ }^{41}$ Phone interview with Siegfried Reiprich, Director of the Foundation of Saxon Memorials, 9 August 2019; “Entscheidung über Untersuchungsausschuss zum Fall Knabe verschoben,” Der 
Tagesspiegel, 22 February 2019.

${ }^{42}$ Martin Trefzer, AfD member of Berlin parliament, 21 February 2019 (author's translation); available at https://www.youtube.com/watch?v=XDJZ1-LSHjU, accessed 16 February 2020. ${ }^{43}$ N. Wagner, "Soll Wahrheit nicht die Wahrheit bleiben, oder geht sie unter? vos-Mitglieder nehmen eine Einladung der AfD-Fraktion im Thüringer Landtag an,” Freiheitsglocke, September/October 2018 68, no. 791.

${ }^{44}$ Phone interview with Hugo Diederich, 27 March 2019

${ }^{45}$ Hugo Diederich cited in Freiheitsglocke, January/February 2019, available at https://www.vos-ev.de/zeitung/, accessed 16 February 2020.

${ }^{46}$ Norbert Frei, Franka Maubach, Christina Morina, and Maik Tändler, Zur Rechten Zeit. Wider Die Rückkehr Des Nationalismus (Berlin, 2019).

47 “Gutachten stellt Einheitsdenkmal in Frage,” Der Tagesspiegel, 10 September 2018.

${ }^{48}$ Julian Göpffarth, “Activating the socialist past for a nativist future: Far-right intellectuals and the prefigurative power of multidirectional nostalgia in Dresden," Social Movement Studies, forthcoming.

${ }^{49}$ Phone interview with Jörg Kürschner, 29 March 2019.

50 Trefzer (see note 42).

${ }^{51}$ Phone interview with Gisela Rüdiger, 29 March 2019, see also "Ermittler sind mutmaßlichen Holocaust-Leugnern in AfD auf der Spur,” Der Tagesspiegel, 21 November 2018.

52 Phone interview with Hugo Diederich, 27 March 2019.

53 This was Kürschner's assessment but also seems to be the tenor in the mainstream media: “AfD-Parteitag in Hannover: Wer übernimmt das Ruder bei der AfD?” Der Tagesspiegel, 2 December 2017; 2 December 2017; “Die AfD will reifer und klüger geworden sein,” Frankfurter 
Allgemeine Zeitung, 2 December 2017. However, see Pazderski's speech in which he argues that the left in Germany is in cahoots with "Arabic terrorists:" "Antisemitismus-Debatte: SPD empört über Rede Pazderskis,” Frankfurter Allgemeine Zeitung, 4 April 2019.

54 “Die Höcke-Rede von Dresden in Wortlaut-Auszügen. Dokumentation,” Die Zeit, 18 January 2017.

${ }^{55}$ https://www.amadeu-antonio-stiftung.de/pressemitteilungen/zum-fachworkshop-derrechte-rand-der-ddr-aufarbeitung/, accessed 16 February 2020.

${ }^{56}$ Hubertus Knabe, "Der Blick nach rechts," 3 March 2019; available at https://hubertusknabe.de/der-blick-nach-rechts/, accessed 16 February 2020.

${ }^{57}$ Albert O. Hirschman, "Exit, Voice, and the Fate of the German Democratic Republic: An Essay in Conceptual History," World Politics 45, no. 2 (1993): 173-202. 